2011-08

\title{
In situ observations of fish associated with coral reefs off Ireland
}

\author{
Soffker, M
}

http://hdl.handle.net/10026.1/1329

10.1016/j.dsr.2011.06.002

Deep Sea Research Part I: Oceanographic Research Papers

Elsevier BV

All content in PEARL is protected by copyright law. Author manuscripts are made available in accordance with publisher policies. Please cite only the published version using the details provided on the item record or document. In the absence of an open licence (e.g. Creative Commons), permissions for further reuse of content should be sought from the publisher or author. 


\title{
In situ observations of fish associated with coral reefs off Ireland
}

\author{
M. Söffker ${ }^{\text {a,* }}$, K.A. Sloman ${ }^{\text {b }}$, J.M. Hall-Spencer ${ }^{c}$ \\ ${ }^{a}$ College of Life and Environmental Sciences, School of Biosciences, University of Exeter, Hatherly Laboratories, Prince of Wales Road, Exeter EX4 4PS, Devon, UK \\ ${ }^{\mathrm{b}}$ School of Science, University of the West of Scotland, Paisley, Scotland, UK \\ ' School of Marine Science and Engineering, University of Plymouth, Plymouth, Devon, UK
}

\section{A R T I C L E I N F O}

\section{Article history:}

Received 18 April 2011

Received in revised form

1 June 2011

Accepted 13 June 2011

Available online 8 July 2011

\section{Keywords:}

Cold-water corals

Continental Slope

Fish abundance

Fish community composition

Lepidion eques

Lophelia pertusa

Northeast Atlantic

Porcupine Bank

Remotely Operated Vehicle (ROV)

observations

\begin{abstract}
A B S T R A C T
The abundance and behaviour of fish on and around coral reefs at Twin Mounds and Giant Mounds, carbonate mounds located on the continental shelf off Ireland (600-1100 m), were studied using two Remotely Operated Vehicle (ROV) dives. We recorded 30 fish taxa on the dives, together with three species of Scleractinia (Lophelia pertusa, Madrepora oculata and Desmophyllum cristagalli) and a diverse range of other corals (Antipatharia, Alcyonacea, and Stylasteridae). Stands of live coral provided the only habitat in which Guttigadus latifrons was observed whereas Neocyttus helgae was found predominantly on structural habitats provided by dead coral. Significantly more fish were found on structurally complex coral rubble habitats than on flatter areas where coral rubble was clogged with sand. The most common species recorded was Lepidion eques (2136 individuals), which always occurred a few $\mathrm{cm}$ above bottom and was significantly more active on the reefs than on sedimentary habitats. Synaphobranchus kaupii (1157 indiv.), N. helgae (198 indiv.) and Micromesistius poutassou (116 indiv.) were also common; S. kaupii did not exhibit habitat-related differences in behaviour, whilst $N$. helgae was more active over the reefs and other structured habitats whereas $M$. poutassou was more active with decreasing habitat complexity. Trawl damage and abandoned fishing gear was observed at both sites. We conclude that Irish coral reefs provide complex habitats that are home to a diverse assemblage of fish utilising the range of niches occurring both above and within the reef structure.
\end{abstract} (c) 2011 Elsevier Ltd. All rights reserved.

\section{Introduction}

Some cold-water corals live in such dense aggregations that they provide structurally complex habitats which support a diverse assemblage of associated invertebrate life (Le Danois, 1948; BurdonJones and Tambs-Lyche, 1960; Buhl-Mortensen and Mortensen, 2004; Metaxas and Davis, 2005; Mortensen et al., 2008) and fish (Auster, 2005; Costello et al., 2005; Reed et al., 2006; Ross and Quattrini, 2007; Roberts et al., 2008; Harter et al., 2009). Cold-water coral reefs have been classified as 'Essential Fish Habitat' (EFH) in the western Pacific (Witherell and Coon, 2000). While it is debatable whether cold-water corals are 'essential' to fish, as the fish recorded to date may survive well in other habitats, it is clear that corals provide an important source of three dimensional structure in the predominantly sedimentary habitats of deeper waters (Auster, 2005, Roberts et al., 2008; Harter et al., 2009). A comparison of visual surveys at eight locations from Ireland to Norway led Costello et al. (2005) to conclude that reefs formed by Lophelia pertusa attract elevated concentrations of fish in the NE Atlantic. These authors tentatively related the elevated abundance of fish to the occurrence of reefs in waters rich in

\footnotetext{
* Corresponding author. Tel.: +1 392723786.

E-mail address: mks204@exeter.ac.uk (M. Söffker).
}

zooplankton (benefiting zooplanktivorous fish) at sites with increased availability of benthic invertebrates (benefiting invertivores). This combination of elevated zooplankton and benthic invertebrates provides appropriate habitat for at least some of the fish recorded (rockfish, Sebastes spp.). Faunal abundance and diversity on coral sites is consistently higher compared to near-by non-coral sites (Mortensen et al., 2008; Roberts et al., 2008; D'Onghia et al., 2010; Du Preez and Tunnicliffe, 2011), suggesting corals may function as refuge; for some species, the provided structure is a significant factor (Du Preez and Tunnicliffe, 2011). Husebø et al. (2002) conclude that in Norway the $L$. pertusa reefs were used by the tusk Brosme brosme for feeding and for physical shelter by the ocean perch Sebastes marinus, and Mediterranean L. pertusa and Madrepora sp. reefs were nurseries e.g. for Helicolenus dactylopterus (rockfish), Merluccius merluccius (European hake), Micromesistius poutassou (blue whiting), or Phycis blennoides, of which some are commercially exploited species (D’Onghia et al., 2010).

Throughout the world, cold-water coral habitats are highly vulnerable to the impacts caused by current fishing practices. These impacts are long-lasting and visible even after many years of closure to fisheries (Althaus et al., 2009). Bottom-trawling in particular can quickly damage coral structures that take thousands of years to develop, so an understanding of the ecological role of cold-water coral reefs is important for the sustainable 
management of fisheries (Hall-Spencer et al., 2002; Koslow, 2007). In the NE Atlantic, complaints from long-line fishermen led to a ban on trawling within selected coral-rich provinces off Norway (Fosså and Alvsvåg, 2003). In 2003, an area called the 'Darwin Mounds' off NW Scotland became the first cold-water coral protected area in the European Union (Commission Regulations EC 1475/2003 and 263/2004, Davies et al., 2007) and was followed in 2007 by further bans on trawling by the EU and the North East Atlantic Fisheries Commission on coral-rich areas around Hatton and Rockall Banks west of Scotland (NEAFC Recommendation IX-2007). Currently there is no protection of coral-rich provinces within the Irish Exclusive Economic Zone but the present study contributes to a rapidly increasing body of evidence concerning the importance of coral rich areas off Ireland (De Mol et al., 2002; Hall-Spencer et al., 2002; Freiwald and Roberts, 2005; Roberts et al., 2008; Dorschel et al., 2009).

Extensive trawling surveys have provided a detailed overview of the benthic fish assemblages of the NE Atlantic (e.g. Haedrich and Merrett, 1988; Merrett et al., 1991; Gordon and Bergstad, 1992; Merrett, 1992; Gordon et al., 1996; Bergstad et al., 1999) with studies focussed mainly on commercially important families such as the gadoids and macrourids (e.g. Mauchline and Gordon, 1984; Kelly et al., 1997; Coggan et al., 1999). Baiting experiments have provided information about population densities, swimming speeds and activity levels of some deepwater fish (Armstrong et al., 1992; Collins et al., 1999), and in recent years behavioural observations of benthic deepwater fish communities have been made using submersibles and ROVs (Johnson et al., 2003; Widder et al., 2005; Lorance and Trenkel, 2006; Ross and Quattrini, 2007). For example, the behavioural ecology of seven benthic fish found in the North Eastern Atlantic was described (Lorance et al., 2002; Uiblein et al., 2002, 2003) along with consideration of how fish species associate with specific habitat types and how habitat type influences fish behaviour (Uiblein et al., 2003).
Here, we present an analysis of ROV footage to compare the benthic fish communities on and around coral reefs on the Porcupine Bank in the NE Atlantic. Descriptions of the study area and some preliminary expedition results have been published within Myers and Hall-Spencer (2004) and Wheeler et al. (2005). We assess the association of fish species with different substrate types and note and compare evidence of fishing activity around the reefs. As little is known about the deep-sea fish we were able to observe, we describe in detail the behaviour of the three most abundant species across a range of habitat types.

\section{Methods}

We studied fish associations on and around coral reefs on Twin Mounds and Giant Mounds which are carbonate mounds situated $9 \mathrm{~km}$ apart on Porcupine Bank in the NE Atlantic (Fig. 1, Table 1). Geological and physical features of Twin Mounds and Giant Mounds were recently described by Dorschel et al. (2009). Video was collected during Expedition ARK-XIX/3a in June 2003 using ROV 'Victor 6000' (operated by IFREMER) aboard the RV 'Polarstern' (operated by the Alfred Wegener Institute).

Observations were made throughout each dive using only the main colour camera, pointing at a $30^{\circ}$ angle downwards-forward. A four point parallel laser system (distance between two opposite points $=23 \mathrm{~cm}$ ) was available to assess object size, although this was only accurate when the target was perpendicular to the laser beams. Although most of each dive was spent filming a $2.5 \mathrm{~m}$ wide strip of seabed with the ROV on average $2.65 \mathrm{~m}$ (all data collected was observed $<5 \mathrm{~m}$ ) above bottom, the data do not represent a true transect. As there was some variation in altitude and each site was passed over only once, no true replication of observations was possible. Consequently, our data are more qualitative than quantitative. However, acknowledging the problems associated with observing

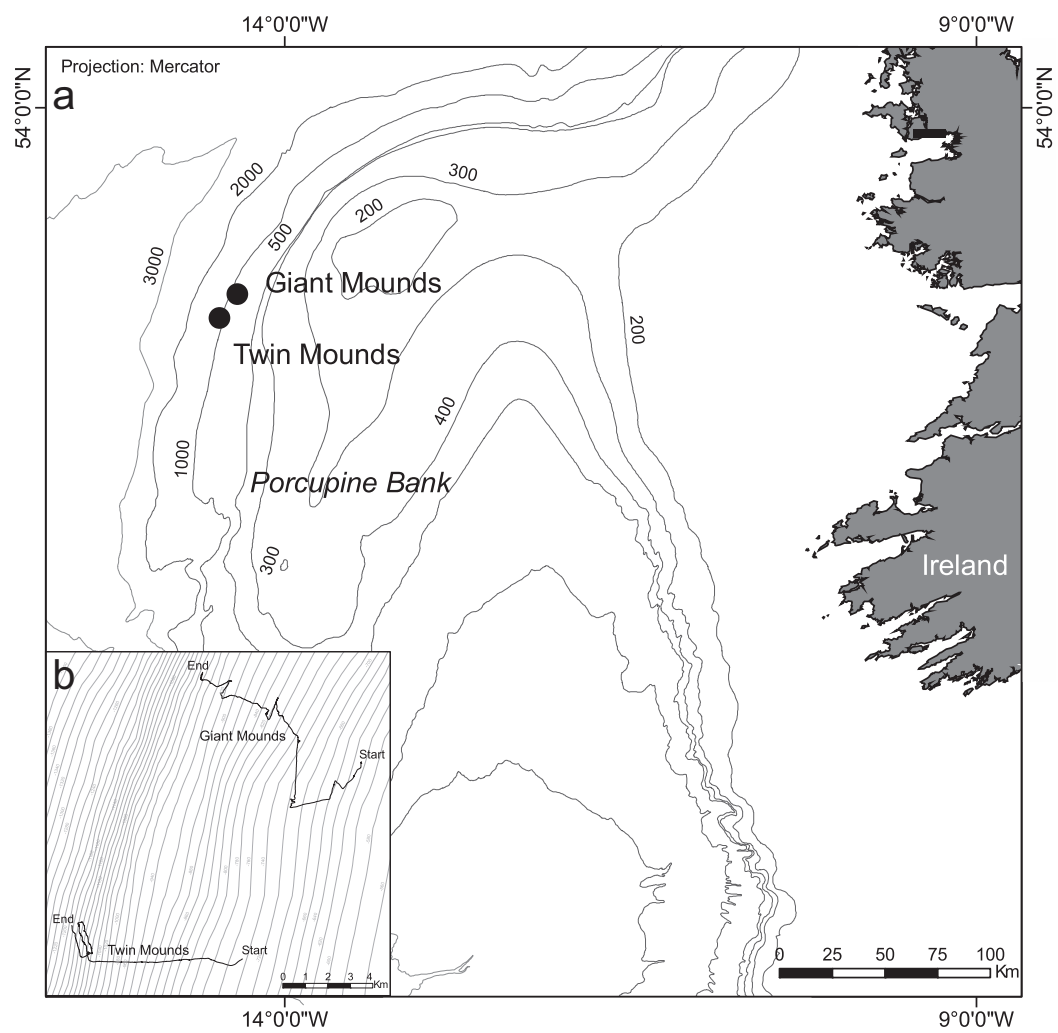

Fig. 1. (a) Study sites at Twin Mounds and Giant Mounds at Porcupine Bank, Northeast Atlantic. (b) Dive tracks at Twin Mounds (13 km) and Giant Mounds (14 km). 
Table 1

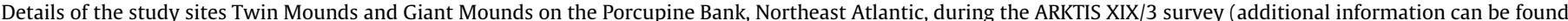
in the cruise report under http://epic.awi.de/Publications/BerPolarforsch2004488.pdf and in Dorschel et al., 2009).

\begin{tabular}{|c|c|c|}
\hline & Twin Mounds & Giant Mounds \\
\hline Depth (m) & $750-1120$ & $650-1060$ \\
\hline Date and time of survey & $12.06 .200316: 03: 44$ to 13.06 .2003 09:43:04 & 14.06.2003 08:05:28 to $15.06 .200303: 14: 28$ \\
\hline Start coordinates & $53^{\circ} 05^{\prime} 25^{\prime \prime} \mathrm{N} 14^{\circ} 48^{\prime \prime} 05^{\prime \prime} \mathrm{W}$ & $53^{\circ} 10^{\prime \prime} 16^{\prime \prime} \mathrm{N} 14^{\circ} 43^{\prime \prime} 37^{\prime \prime} \mathrm{W}$ \\
\hline End coordinates & $53^{\circ} 06^{\prime} 13^{\prime \prime} \mathrm{N} 14^{\circ} 55^{\prime \prime} 19^{\prime \prime} \mathrm{W}$ & $53^{\circ} 11^{\prime} 33^{\prime \prime} \mathrm{N} 14^{\circ} 47^{\prime} 06^{\prime \prime} \mathrm{W}$ \\
\hline Dive track length $(\mathrm{km})$ & 13 & 14 \\
\hline Studied footage time $(\mathrm{h})$ & 16.5 & 17.0 \\
\hline Velocity range (knots) & $0.0-1.3$ & $0.0-1.3$ \\
\hline
\end{tabular}

Table 2

Behavioural categories used to classify observed fish behaviour during each dive.

\begin{tabular}{ll}
\hline Behaviour & Description \\
\hline 'stationary' & Fish sitting on the seabed or showing no locomotion movements. \\
'station holding' & Fish swimming sufficiently against the current to hold position over the substrate. \\
'associated' & Fish observed in or associated with 3D structures. \\
'active forward' & Fish swimming actively forward (displacement). \\
'disturbed' & Abrupt changes in direction, accelerating swimming speed, sudden increased fin beating or apparent disorientation. \\
\hline
\end{tabular}

deep sea fish communities by ROV (Adams et al., 1995; Trenkel et al., 2004a, 2004b), it was possible to reliably estimate fish abundance and to make some quantitative measurements of fish behaviour. Due to the patchiness and high spatial and area heterogeneity of substrates, the most reliable and robust method was to calculate average fish abundance over an entire substrate (see below).

Footage was only considered less than $5 \mathrm{~m}$ from the sea bed and at ROV speeds below 1.3 knots. Footage was excluded if the ROV was stationary for a period of time. From footage suitable for data collection, a still image was taken every minute and the substrate type below the ROV was noted. The substrate type was divided into four categories (coral, sand, bedrock and threedimensional (3D) structured, which consisted of patchy or dense dropstones and rocky outcrops). The coral habitat was further divided into the following sub-categories; (1) live coral, (2) coral rubble, (3) mixed living and dead coral and (4) sand-clogged coral, based on the expedition cruise report (Klages et al., 2004) which is similar to other published studies (Dorschel et al., 2007; Dorschel et al. 2009). This allowed the total time of footage over a particular substrate type to be calculated for each dive, using a total of 2029 still images. The footage was then analyzed again; this time, each fish encountered was recorded and for each fish observed the fish species, body position in relation to sea bed, behaviour (Table 2), substrate type and depth, and any evidence of fishing were noted. Combining the data on time spent over each substrate and fish occurrences, we adopted the 'fish counts per minute' method of Costello et al. (2005) to compare fish abundance between habitats, i.e. the total number of fish observed in each habitat was divided by the minutes spent filming in each habitat.

Evidence of fishing at the sites was noted in each of the 2029 still images and frequency of trawling damage occurring at each site and on each substrate type calculated from these.

To compare abundance of fish on each substrate type (as fish per minute counts), a Fisher's exact test for count data in contingency was used to test the difference between the observed and the exact probability (expected) of abundance (Fisher, 1922). Within a site, we tested whether the observed abundance of fish across substrates differed significantly from that expected if they were equally distributed across all substrates. The behavioural patterns of five fish species were considered in detail. For each species, firstly, within one habitat, the frequency a specific behaviour was observed for was compared to see if some behaviours
Table 3

Percentage of total time each substrate category was filmed during each dive.

\begin{tabular}{lcc}
\hline Substrate & Twin Mounds (\%) & Giant Mounds (\%) \\
\hline Coral & 48.4 & 50.3 \\
-live coral & 5.9 & 15.5 \\
-dead coral & 36.5 & 6.9 \\
-mixed dead and living coral & 1.7 & 14.6 \\
-sand-clogged coral & 4.3 & 13.2 \\
Bedrock & 1.0 & 9.5 \\
Sand & 35.9 & 30.0 \\
3D structured & 14.6 & 10.2 \\
\hline
\end{tabular}

were performed more frequently than would be expected by chance. Secondly, across different habitats, the performance of each specific behaviour was compared to understand if that behaviour was performed equally in each habitat. Fisher's exact test was also applied to test whether trawling damage was independent of substrate type, assuming equal probabilities of trawling damage on all substrates. All statistical analysis was carried out using the software package $\mathrm{R}$ (Crawley, 2007).

\section{Results}

The amount of time spent over each substrate is shown in Table 3. The live coral framework was dominated by L. pertusa and Madrepora oculata, (although Desmophyllum cristagalli was also seen), but solitary antipatharian and anthozoan corals, as well as anthozoan reefs were also observed. The adjacent coral rubble zones supported a rich assemblage of sessile and vagile invertebrate fauna. Large particle aggregates ('marine snow') and swarms of planktonic copepods were observed for the majority of the dives and were abundant near the seabed. Fish abundance and community composition differed between sites (Table 4) although the two commonest species, the North Atlantic codling Lepidion eques and the northern cutthroat eel Synaphobranchus kaupii, were recorded in similar abundances at each site. At Twin Mounds the false boarfish Neocyttus helgae was the third most common species observed, but this species was not seen at Giant Mounds. Conversely, the $M$. poutassou was the third most abundant species at Giant Mounds, but was not observed at Twin Mounds. 
Table 4

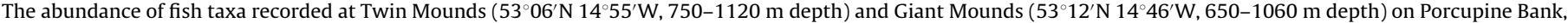

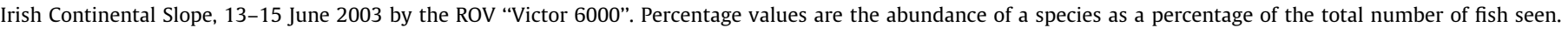

Twin Mounds

\begin{tabular}{l}
\hline Fish taxa \\
\hline Lepidion eques Günther, 1887 \\
Synaphobranchus kaupii Johnson, 1862 \\
Neocyttus helgae Holt and Byrne, 1908 \\
Unidentified Macrouridae \\
Guttigadus latifrons Holt and Byrne, 1908 \\
Molva dypterygia Pennant, 1784 \\
Molva sp. \\
Mora moro Risso, 1810 \\
Chimaera monstrosa Linnaeus, 1758 \\
Notacanthus bonapartei Risso, 1840 \\
Coryphaenoides rupestris Gunnerus, 1765 \\
Nezumia aequalis Günther, 1878 \\
Scyliorhinidae \\
Lophius sp. \\
Rajidae \\
Unidentified Moridae \\
Hoplostethus atlanticus Collett, 1889 \\
Molva molva Linnaeus, 1758 \\
Phycis blennoides Brünnich 1768 \\
Unidentified Gadiform (possibly Merluccius merluccius Linnaeus, 1758) \\
Helicolenus dactylopterus Delaroche 1809 \\
Deania calcea Lowe, 1839 \\
Trachyscorpia cristulata Goode and Bean, 1896 \\
Arctozenus risso Bonaparte, 1840 \\
Centrophorus sp. \\
Squalidae \\
unidentified \\
Total
\end{tabular}

Giant Mounds

\begin{tabular}{|c|c|c|c|c|}
\hline Individuals & $\%$ & Fish taxa & Individuals & $\%$ \\
\hline 1286 & 45.46 & Lepidion eques Günther, 1887 & 850 & 42.99 \\
\hline 652 & 23.05 & Synaphobranchus kaupii Johnson, ,1862 & 504 & 25.49 \\
\hline 198 & 7.00 & Micromesistius poutassou Risso, 1827 & 116 & 5.87 \\
\hline 120 & 4.24 & Unidentified Macrouridae & 42 & 2.12 \\
\hline 53 & 1.87 & Helicolenus dactylopterus Delaroche, 1809 & 35 & 1.77 \\
\hline 26 & 0.92 & Mora moro Risso, 1810 & 22 & 1.11 \\
\hline 24 & 0.85 & Phycis blennoides Brünnich, 1768 & 21 & 1.06 \\
\hline 22 & 0.78 & Coryphaenoides rupestris Gunnerus, 1765 & 18 & 0.91 \\
\hline 20 & 0.71 & Notacanthus bonapartei Risso, 1840 & 16 & 0.81 \\
\hline 16 & 0.57 & Deania calcea Lowe, 1839 & 12 & 0.61 \\
\hline 15 & 0.53 & Nezumia aequalis Günther, 1878 & 12 & 0.61 \\
\hline 12 & 0.42 & Chimaera monstrosa Linnaeus, 1758 & 10 & 0.51 \\
\hline 12 & 0.42 & Lophius sp. & 7 & 0.35 \\
\hline 11 & 0.39 & Arctozenus risso Bonaparte, 1840 & 7 & 0.35 \\
\hline 9 & 0.32 & Hoplostethus atlanticus Collett, 1889 & 5 & 0.25 \\
\hline 9 & 0.32 & Molva dypterygia Pennant, 1784 & 5 & 0.25 \\
\hline 8 & 0.28 & Molva sp. & 5 & 0.25 \\
\hline 7 & 0.25 & Centrophorus sp. & 1 & 0.05 \\
\hline 7 & 0.25 & cf. Gaidropsarus sp. & 1 & 0.05 \\
\hline 6 & 0.21 & Molva molva Linnaeus, 1758 & 1 & 0.05 \\
\hline 5 & 0.18 & Rajidae & 1 & 0.05 \\
\hline 4 & 0.14 & Trachyscorpia cristulata Goode and Bean, 1896 & 1 & 0.05 \\
\hline 4 & 0.14 & & & \\
\hline 2 & 0.07 & & & \\
\hline 1 & 0.04 & & & \\
\hline 1 & 0.04 & & & \\
\hline 299 & 10.81 & unidentified & 285 & 14.42 \\
\hline 2829 & & Total & 1977 & \\
\hline
\end{tabular}

At both sites, more fish were found in 3-D structured habitats than in coral habitats (Fig. 2A), although only at Giant Mounds was the association of fish with specific habitats significantly different from random (Fisher's exact test, $p=0.011$ ). The abundance of fish was, as a trend, associated with specific coral habitats (although not significantly, Fisher's exact test, $p=0.09$ ) at Giant Mounds, with the highest levels of fish found on rubble habitats, fewer on live coral thickets and fewer still in areas of decreasing habitat complexity; although a similar pattern was seen at Twin Mounds (Fig. 2B), the association was not significant (Fisher's exact test, $p=0.12$ ).

The behaviour of the most common fish found on and around the reefs differed between species and some species showed clear differences in behaviour between different habitats (Fig. 3). Bedrock habitats comprised less than $1 \%$ of footage at Twin Mounds and, therefore, were excluded from behavioural analyses at both sites. Sixty to eighty percent of observed S. kaupii, a scavenging eel, were performing active behaviour regardless of habitat (Fig. 3A). Lepidion eques was always recorded within a few centimetres above bottom and displayed a larger variety of behaviours. There was a tendency for $L$. eques to be found associated with structures that were emergent from the seabed, such as boulders, drop stones and solitary corals. $L$. eques were more stationary and less active on sandy substrata at both sites (Fisher's exact test, $p=<0.001$ at both sites; Fig. 3B) with more individuals associated with a 3-D structure (Fisher's exact test, $p=0.006$ for Giant Mounds, $p=0.008$ at Twin Mounds). Neocyttus helgae, a laterally flattened fish, was most active above coral 3-D structured habitats (Fisher's exact test, $p=0.007$ ) whereas $M$. poutassou, a fusiform fish, appeared to be more active above sandy substrata than coral (Fig. 3C), although this was not statistically significant (Fisher's exact test, $p=0.71$ ).

Interestingly, two species of fish were particularly associated with coral habitats. $N$. helgae presence was tied to coral habitat
(Fisher's exact test, $p<0.001$ ) and it was found most frequently above dead coral rubble (Fisher's exact test, $p=0.06$ ) whereas Guttigadus latifrons was mainly found amongst dense living coral thickets (Fisher's exact test, $p=0.006$ ), and was not observed on non-coral habitat. The behaviour of G. latifrons differed between dead and living coral habitat (Fig. 4). In particular, G. latifrons spent more time active and within living coral (Fisher's exact test, $p=0.08$ ) whereas when it was sighted in association with dead coral it tended to be more stationary and less hidden. On one occasion on Giant Mounds, a fish strongly resembling Gaidopsarus $s p$. was found among living pink $L$. pertusa. However, we cannot be certain about the identification of this individual.

At Giant Mounds the reefs appeared not to be heavily impacted by trawling, although one monofilament net was seen, filled with fresh coral rubble and broken live coral fragments. No trawl tracks could be seen in the proximity of the net, suggesting that this was a lost gill-net. At Twin Mounds there was widespread evidence of the impacts of fishing where recently broken coral, lost gear and trawl tracks seen during $14 \%$ of the recording time (as opposed to $4 \%$ at Giant Mounds). The occurrence of fishing evidence at Twin Mounds was linked to substrate type (Fisher's exact test, $p=0.0008$ ), positively correlated with patchy live coral (boulders on sand, overgrown with coral such as drop stones) and a negatively correlated with sandy coral rubble and dead coral.

\section{Discussion}

Dense aggregations of scleractinian corals were discovered in deep waters off SW Ireland during dredging surveys aboard HMS Porcupine (Duncan, 1873) but the invertebrate diversity of these habitats did not begin to be fully appreciated until the more detailed dredge and grab studies of Le Danois (1948). Traditionally, scientific fish trawls were avoided on these grounds, due to 
A

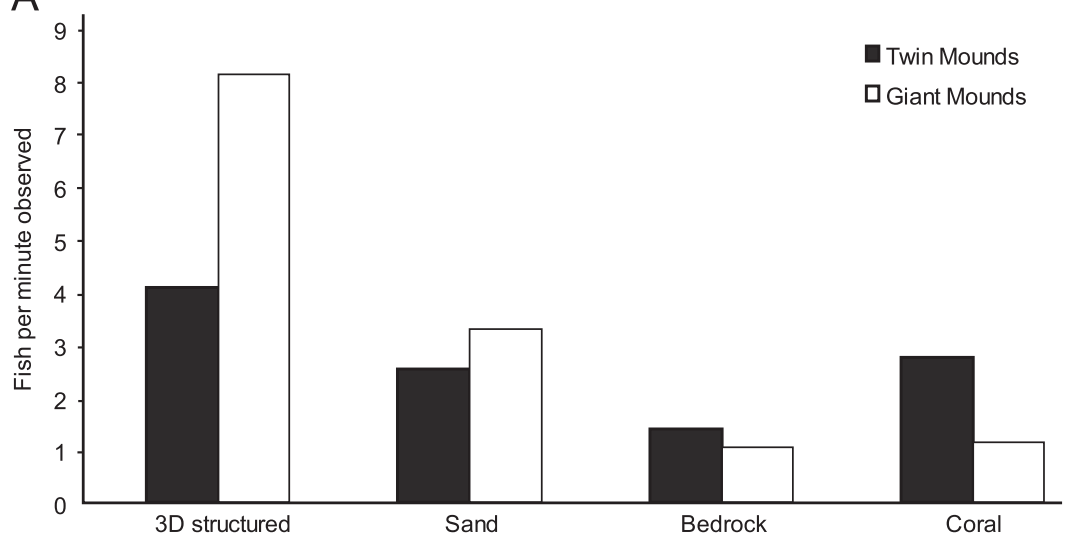

B

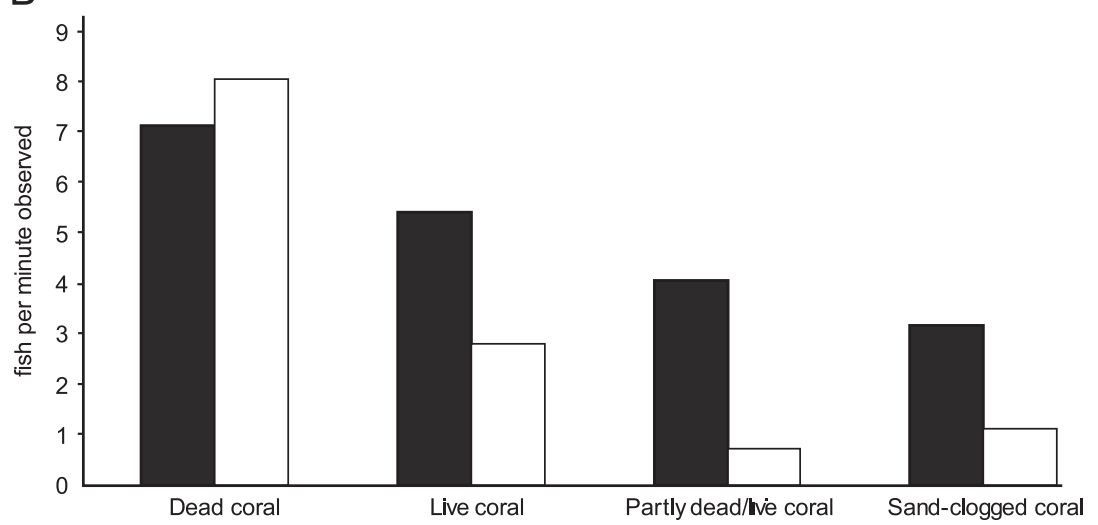

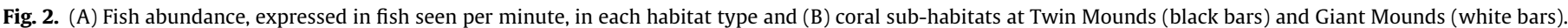

the dangers of losing the gear, but the advent of robust rockhopper trawls in the late 1980s allowed large-scale commercial fishing operations to expand into the coral-rich provinces off Ireland targeting demersal species such as roundnose grenadier, Coryphaenoides rupestris, orange roughy, Hoplostethus atlanticus, leafscale gulper shark, Centrophorus squamosus and the Portuguese dogfish, Centroscymmus coelolepis, with a range of large fish species caught as by-catch (Hall-Spencer et al., 2002). Although an analysis of commercial trawls can tell us which fish species occur around Irish coral reefs, detailed insights into the interactions of demersal fish on these deep-water reefs had to wait until the direct observations of Costello et al. (2005). Their observations of the Irish coral reefs recorded 13 fish taxa (6 identified to species, 1 to genus, 3 to family and 3 unknown), based on ca $3 \mathrm{~h}$ of video from a drop-down camera and ca $4 \mathrm{~h}$ worth of still-photographs taken every $12 \mathrm{~s}$ from a camera suspended below the ship. In the present study we analysed $33.5 \mathrm{~h}$ of high quality ROV video, observing 30 taxa (18 identified to species, 5 to genus, 7 to family). We found $S$. kaupii and $L$. eques to be the most common during the course of our surveys; Costello et al. (2005) also found that S. kaupii and fish from the Moridae family were common over the reefs.

A remarkable difference between the areas surveyed was the site-dependent presence/absence of $M$. poutassou and $N$. helgae. Micromesistius poutassou is a migrant species in Rockall Trough and feeds mainly on zooplankton, but also on other pelagic crustaceans and cephalopods (Mauchline and Gordon, 1984). Cold-water corals feed mainly on zooplankton and organic matter (Mortensen, 2001; Freiwald, 2002; Davies et al., 2009), and thus grow in places of sufficient plankton and organic matter input (Thiem et al., 2006; Kiriakoulakis et al., 2007); it is not surprising therefore to find this fish species above coral reef sites. The observed absence of M. poutassou at Twin Mounds could be due to fishing, but other factors could also be responsible such as abundance of food. The presence of $N$. helgae may also be associated with the rich zooplanktonic input of coral sites (Auster 2005) but why this fish was not observed at Giant Mounds is unknown. Information gathered from other ROV cruises indicates that the high abundance of $N$. helgae seen at Twin Mounds is rather exceptional (P. Lorance, Ifremer Nantes, France, pers. comm. 2006).

Previous research concerning the use of cold-water corals by fish has tended to view the coral structures as one habitat type (Witherell and Coon, 2000; Krieger and Wing, 2002; Auster 2005; Auster et al., 2005; Morgan et al., 2005). As with Costello et al. (2005, but also Ross and Quattrini, 2007; Roberts et al., 2008; Harter et al., 2009; Du Preez and Tunnicliffe, 2011) we divided the reefs into sub-habitats and found that living and dead coral structures supported different fish communities at both study sites, with more fish living in the coral rubble zone than in the areas of live coral. This may relate to food availability since the benthic invertebrate fauna appeared to be more diverse and abundant within rubble zones than in live coral areas (see also Roberts et al., 2008). It is well documented that deep sea coral structures support a high diversity of fish (Costello et al., 2005; Koenig et al., 2005; Reed et al., 2006; Parrish 2006), but it appears this may be due to the three-dimensional structure of the coral rather than the biotic properties of the reef (Harter et al., 2009). The association of particular fish species to deep sea corals has been shown in the western Atlantic off the coast of the U.S. (Ross and Quattrini, 2007), but data for the eastern Atlantic has not yet yielded such conclusive evidence. In our dive footage, one species (G. latifrons) was particularly associated with live coral and may, therefore, depend on the presence of cold-water coral reefs for shelter or food. The natural history of G. latifrons has, to our knowledge, not yet been studied. This species has small pectoral 

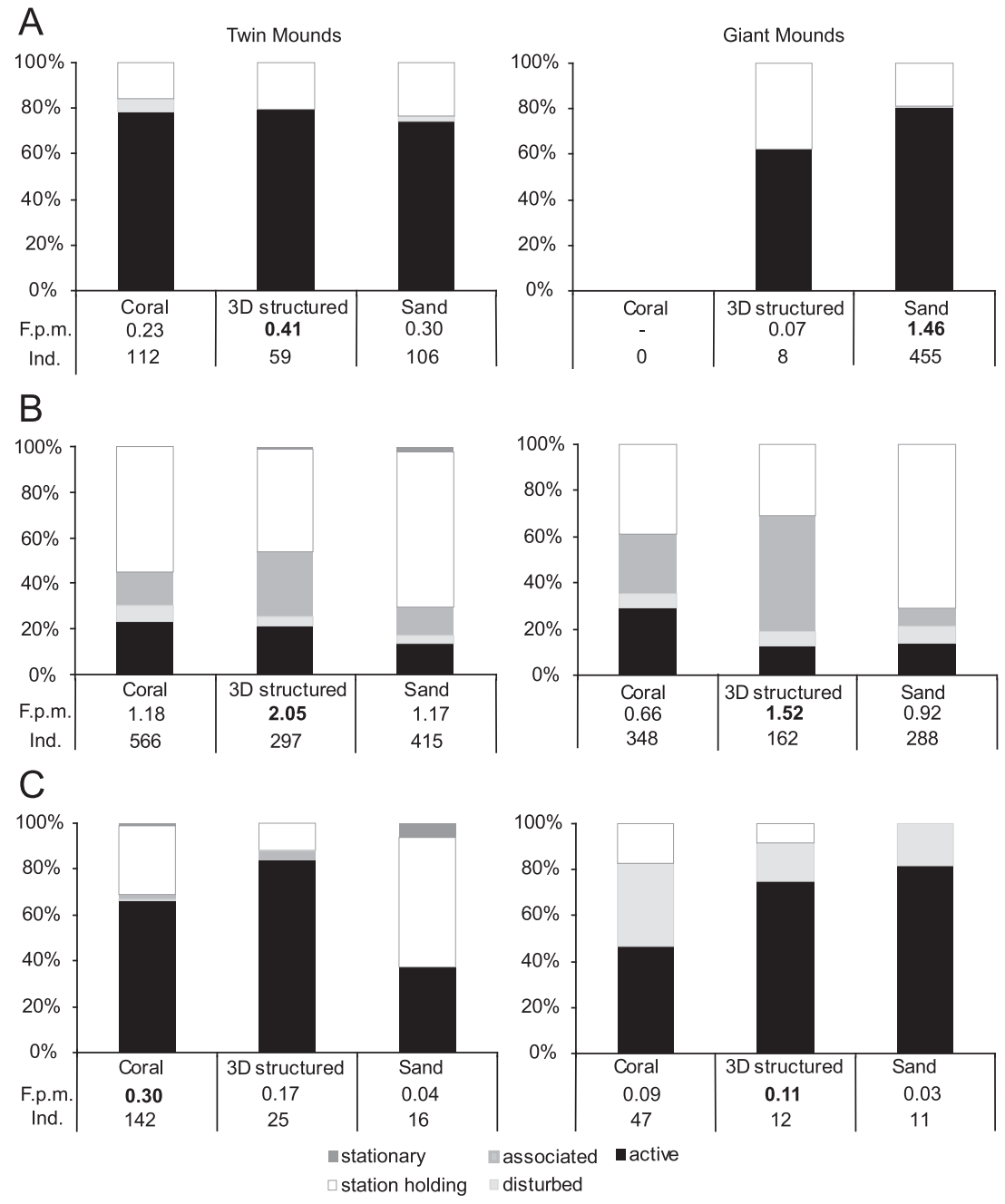

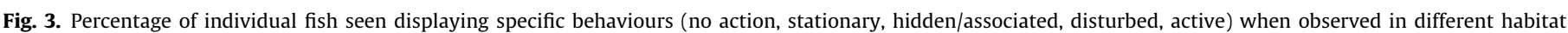

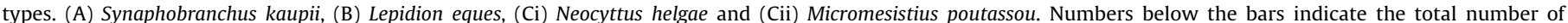

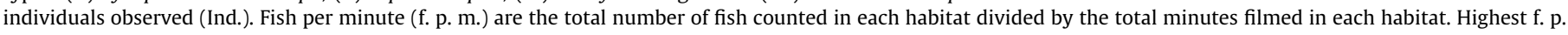
$\mathrm{m}$. counts are highlighted in bold font.
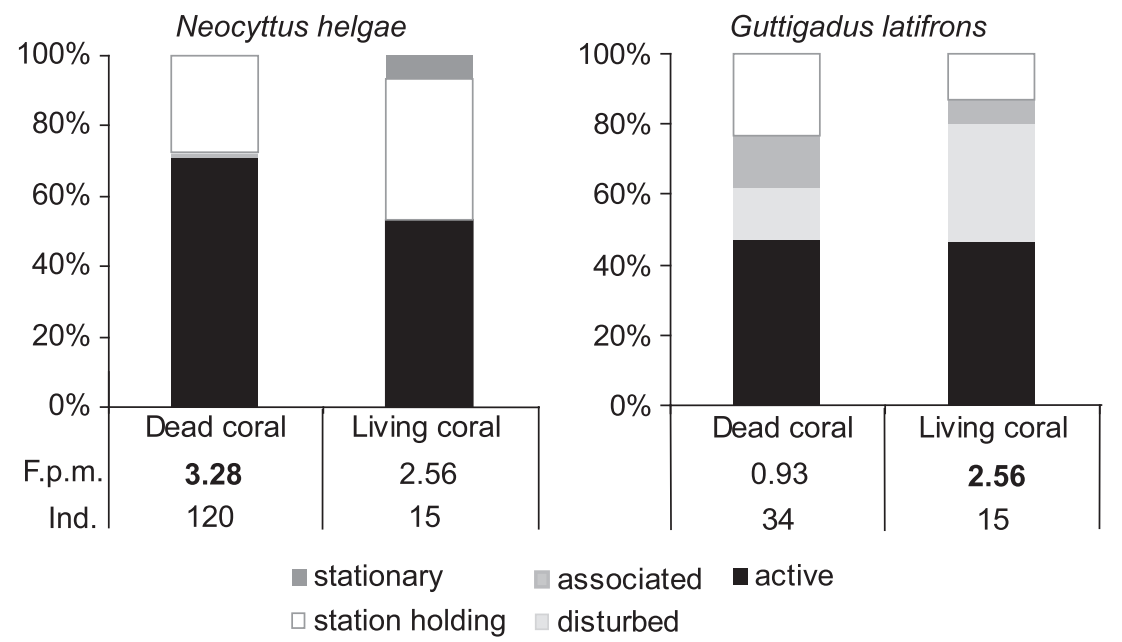

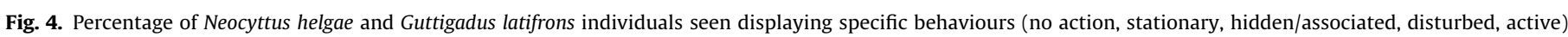

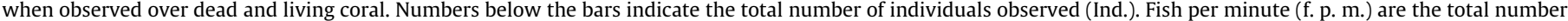
of fish counted in each habitat divided by the total minutes filmed in each habitat.

fins and a small isocercal caudal fin. Forward movement was elicited through anguilliform undulations. Guttigadus latifrons has a wide mouth gape typical of the Gadidae.
The behaviour of five fish species was studied in more detail. At both sites, we found that $S$. kaupii moved actively forward irrespective of substrate type. Similar observations have been 
made by Uiblein et al. (2002, 2003), where active forward moving behaviour of $S$. kaupii remained the most observed behaviour in different environments. For the other four species, substrate type influenced fish behaviour. The bentho-pelagic species M. poutassou, which is known to migrate from near the seabed up into the water column depending on season and time of day, increased activity over sandy substrates. Over sand these fish were all swimming actively forwards, maybe to optimise prey location; they are known to eat zooplankton, small crustaceans and cephalopods (Cohen et al., 1990).

Lepidion eques were most commonly found in association with three-dimensional structured habitats where they were significantly more active than when seen on sandy habitats. This increased activity could be due to the animals searching for crustaceans and polychaetes, their preferred prey items (Whitehead et al., 1989). On sandy habitats $L$. eques were found within a few centimetres above bottom, generally stationary, which may help to avoid attracting predators in this exposed environment. In a behavioural study conducted in the Bay of Biscay on several deep sea fish species (Uiblein et al., 2003) L. eques was similarly observed displaying station holding behaviour in sandy habitats. The authors suggested that the station holding behaviour might be typical for benthic gadoid species in the deep sea, and noted that they observed similar behaviour in Molva molva and Mora moro during their dives. At Twin and Giant Mounds we saw the same behavioural pattern for M. moro as the Uiblein et al. (2003) study, but the most common behaviour observed for M. molva and Molva dypterygia was slow active forward movements. The other observed gadoid fish, P. blennoides, was often seen moving slowly and close to the substrate, with its long barbels touching the ground. Both $L$. eques and M. moro belong to the family of Moridae, so while we cannot confirm the previous observations from Uiblein et al. (2003) for all gadoid species seen during the dives, we can verify that station holding was the typical behaviour for the observed morid species.

The activity of $N$. helgae increased with increasing habitat structure; its deep, laterally flattened, round, body shape is well suited for holding position in or near vertical structures, and has been observed previously associated with structured habitats such as boulders and coral reefs (Miller, 2003; Auster, 2005). It feeds on cnidarians and crinoids (Gartner et al., 1997) although Auster et al. (2005) suggest that this species may associate with coral rich areas to profit from abundant zooplankton. In our study $N$. helgae was more frequent in dead coral areas although it did not appear to behave differently on living and dead coral.

When using ROV for visual surveys of deep sea fish abundance and behaviour, the impact of the ROV itself, particularly the light and sound emitted, needs to be considered (Stoner et al., 2008). Several studies have documented the behavioural responses of deep sea fish to ROV presence (Lorance and Trenkel, 2006; Trenkel et al., 2004a, 2004b) and have generally found that active, pelagic fish show the strongest avoidance and disturbance in response to the ROV (Lorance and Trenkel, 2006). Species-specific responses to ROVs are also likely to vary with environmental conditions (Lorance and Trenkel, 2006; Trenkel et al., 2004a). During our analysis we did consider 'disturbed' behaviours in relation to ROV presence and for some species, e.g. G. latifrons, the ROV had a clear affect on behaviour. We cannot exclude the fact that our estimates of abundance were also affected by ROV presence. Numbers of S. kaupii during the two dives may be overestimates as it has been shown previously that $S$. kaupii is attracted to ROV lights, in contrast to fish from the Moridae family (particularly L. eques) which have been observed in higher abundance when ROV lights are dimmed (Trenkel et al., 2004a). Although the use of ROVs is believed to result in reduced bias when used for qualitative assessments of fish communities based on relative abundance in habitats (Stoner et al., 2008), it is to date one of the most useful tools for observations of deep-water animals in their natural environment.

In conclusion, Irish coral reefs provide complex habitats that are home to a diverse assemblage of fish which utilise the range of niches occurring both above and within the reef structure. So far, no corallivore fish have been identified in the deep sea and it seems that the structure provided by dead or living coral is more important for benthic fish communities that the coral organism itself. However, the association of G. latifrons and cf. Gaidropsarus sp. with live coral and the important differences in fish abundance between live coral, dead coral, and other seabed habitats show that seabed features are important for fish diversity. Additionally, the present study found higher fish abundances on complex three-dimensional habitats such as drop-stones. The ecological value of these boulders, which provide habitat for both invertebrates (e.g. corals, sponges, crinoids, crustaceans, Davies et al., 2007; Le Guilloux et al., 2010) and fish (this study) may have been previously underestimated due to their isolated and patchy distribution. This isolated distribution in vast stretches of sand makes them particularly vulnerable to destruction through fishing gear, as these densely populated drop-stones can hardly be detected from the surface.

\section{Acknowledgements}

ROV film is copyright of IFREMER and was collected onboard the RV Polarstern during the Alfred Wegener Institute coordinated cruise ARK-XIX/3a. This work contributes to the EC-funded Framework 7 project Knowledge-based Sustainable Management for Europe's Seas (KnowSeas-226675).

We thank Pascal Lorance and Erwan Le Guilloux (at IFREMER) together with James Maclaine and Nigel Merrett (Natural History Museum, London) for help with fish identifications. We would also like to thank two anonymous reviewers for their valuable comments on a previous draft of this manuscript.

\section{References}

Adams, P.B., Butler, J.L., Baxter, C.H., Laidig, T.E., Dahlin, K.A., Wakefield, W.W. 1995. Population estimates of Pacific coast groundfishes from video transects and swept-area trawls. Fishery Bulletin 93, 446-455.

Althaus, F. Williams, A, Schlacher, TA, Kloser, RJ Green, M.A, Barker, B.A, Bax, N.J., Brodie, P., Schlacher-Hoenlinger, M.A., 2009. Impacts of bottom trawling on deep-coral ecosystems of seamounts are long-lasting. Marine Ecology Progress Series 397, 279-294.

Armstrong, J.D., Bagley, P.M., Priede, I.G., 1992. Photographic and acoustic tracking observations of the behaviour of the grenadier Coryphaenoides (Nematonurus) armatus the eel Synaphobranchus bathybius, and other abyssal demersal fish in the North Atlantic Ocean. Marine Biology 112, 535-544.

Auster, P.J., 2005. Are deep-water corals important habitats for fishes?. In: Freiwald, A., Roberts, J.M. (Eds.), Cold-water Corals and Ecosystems. Springer, Berlin Heidelberg, pp. 761-769.

Auster, P.J., Moore, J., Heinonen, K.J., Watling, L., 2005. A habitat classification scheme for seamount landscapes: assessing the functional role of deep-water corals as fish habitat. In: Freiwald, A., Roberts, J.M. (Eds.), Cold-water Corals and Ecosystems. Springer, Berlin Heidelberg, pp. 747-760.

Bergstad, O.A., Bjelland, O., Gordon, J.D.M., 1999. Fish communities on the slope of the eastern Norwegian Sea. Sarsia 84, 67-78.

Buhl-Mortensen, L., Mortensen, P.B., 2004. Crustaceans associated with the deepwater gorgonian corals Paragorgia arborea (L., 1758) and Primnoa resedaeformis (Gunn, 1763). Journal of Natural History 38, 1233-1247.

Burdon-Jones, C., Tambs-Lyche, H., 1960. Observations on the fauna of the North Brattholmen stone-coral reef near Bergen. Årbok for Universitetet I Bergen. Mat. Naturv. Serie. vol. 4, pp. 1-24.

Coggan, R.A., Gordon, J.D.M., Merrett, N.R., 1999. Aspects of the biology of Nezumia aequalis from the continental slope west of the British Isles. Journal of Fish Biology 54, 152-170.

Cohen, D.M., Inada, T., Iwamoto, T., Scialabba, N., 1990. FAO species catalogue. Vol 10. Gadiform fishes of the world (Order Gadiformes). An annotated and illustrated catalogue of cods, hakes, grenadiers and other gadiform fishes known to date. FAO Fish. Synop. vol. 10, issue 125, 442 p. 
Collins, M.A., Priede, I.G., Bagley, P.M., 1999. In situ comparison of activity in tow deep-sea scavenging fishes occupying different depth zones. Proceedings of the Royal Society London, Series B 266, 2011-2016.

Costello, M.J., McCrea, M., Freiwald, A., Lundälv, T., Jonsson, L., Bett, B.J., van Weering, T.C.E., de Haas, H., Roberts, J.M., Allen, D., 2005. Role of cold-water Lophelia pertusa coral reefs as fish habitat in the NE Atlantic. In: Freiwald, A. Roberts, J.M. (Eds.), Cold-water Corals and Ecosystems. Springer, Berlin Heidelberg, pp. 771-805.

Crawley, M.J., 2007. The R Book. Wiley and Sons, Chichester, UK.

Davies, A.J., Roberts, M.A., Hall-Spencer, J.M., 2007. Preserving deep-sea natural heritage: emerging issues in offshore conservation and management. Biological Conservation 138 (3-4), 299-312.

Davies, A.J., Duineveld, G.C.A., Lavaleye, M.S.S., Bergman, M.J.N., van Haren, H. 2009. Downwelling and deep-water bottom currents as food supply mechanisms to the cold-water coral Lophelia pertusa (Scleractinia) at the Mingulay Reef complex. Limnology and Oceanography 54 (2), 620-629.

De Mol, B., Van Rensbergen, P., Pillen, S., Van Herreweghe, K., Van Rooij, D., McDonnell, A., Huvenne, V.A.I., Ivanov, M., Swennen, R., Henriet, J.P., 2002 Large deep-water coral banks in the Porcupine Basin, southwest of Ireland. Marine Geology 188, 193-231.

D’Onghia, G., Maiorano, P., Sion, L., Giove, A., Capezzuto, F., Carlucci, R., Tursi, A. 2010. Effects of deep-water coral banks on the abundance and size structure of the megafauna in the Mediterranean Sea. Deep-Sea Research II 57, 397-411.

Dorschel, B., Hebbeln, D., Foubert, A., White, M., Wheeler, A.J., 2007. Hydrodynamics and cold-water coral facies distribution related to recent sedimentary processes at Galway Mound west of Ireland. Marine Geology 244, 184-195.

Dorschel, B., Wheeler, A.J., Huvenne, V.A.I., De Haas, H., 2009. Cold-water coral mounds in an erosive environmental setting: TOBI side-scan sonar data and ROV video footage from the northwest Porcupine Bank, NE Atlantic. Marine Geology 264, 218-229.

Duncan, P.M., 1873. A description of the Madreporaria dredged up during the Expeditions of H.M.S. 'Porcupine' in 1869 and 1870. Transactions of the Zoological Society of London 8, 303-344.

Du Preez, C., Tunnicliffe, V., 2011. Shortspine thornyhead and rockfish (Scorpaenidae) distribution in response to substratum, biogenic structures and trawling. Marine Ecology Progress Series 425, 217-231.

Fisher, R.A., 1922. On the interpretation of $\mathrm{X}^{2}$ from contingency tables, and the calculation of p. Journal of the Royal Statistical Society 85, 87-94.

Fosså, J.H., Alvsvåg, J., 2003. Kartlegging og overvåkning av korallrev. In: Asplin, L., Dahl, E. (Eds.) Havets Miljø 2003, Fisken og Havet. Special Issue 2-2003, pp. 62-67.

Freiwald, A., Roberts, J.M., 2005. Cold-water Corals and Ecosystems Erlangen Earth Conference Series. Springer-Verlag, Berlin Heidelberg 1243 pp.

Freiwald, A., 2002. Reef-forming cold-water corals. In: Wefer, G., Billett, D. Hebbeln, D., Jørgensen, B.B., Schlüter, M., van Weering, T. (Eds.), Ocean Margin Systems. Springer-Verlag, Berlin, Heidelberg.

Gartner, J.V., Crabtree, R.E., Sullak, K.J., 1997. Feeding at Depth. In: Randall, D.J. Farell, A.P. (Eds.), Deep-sea fishes. Academic Press, San Diego.

Gordon, J.D.M., Merrett, N.R., Bergstad, O.A., Swan, S.C., 1996. A comparison of the deep-water demersal fish assemblages of the Rockall Trough and Porcupine Seabight, eastern North Atlantic: continental slope to rise. Journal of Fish Biology 49, 217-238.

Gordon, J.D.M., Bergstad, O.A., 1992. Species composition of demersal fish in the Rockall Trough, North-eastern Atlantic, as determined by different trawls. Journal of the Marine Biological Association U.K 72, 213-230.

Haedrich, R.L., Merrett, N.R., 1988. Summary atlas of deep-living demersal fishes in the North Atlantic Basin. Journal of Natural History 22, 1325-1362.

Hall-Spencer, J.M., Allain, V., Fosså, J.H., 2002. Trawling damage to Northeast Atlantic ancient coral reefs. Proceedings of the Royal Society in London, Series B 269, 507-511.

Harter, S.L., Ribera, M.M., Shepard, A.N., Reed, J.K., 2009. Assessment of fish populations and habitat on Oculina Bank, a deep-sea coral marine protected area off eastern Florida. Fisheries Bulletin 107, 195-206.

Husebø, Å., Nøttestad, L., Fosså, J.H., Furevik, D.M., Jørgensen, S.B., 2002. Distribution and abundance of fish in deep-sea coral habitats. Hydrobiologia 471, 91-99.

Johnson, S.W., Murphy, M.L., Csepp, D.J., 2003. Distribution, habitat and behaviour of rockfishes, Sebastes spp., in nearshore waters of southeastern Alaska: observations from a remotely operated vehicle. Environmental Biology of Fishes 66, 259-270.

Kelly, C.J., Conolly, P.L., Bracken, J.J., 1997. Age estimation, growth, maturity and distribution of roundnose grenadier from the Rockall Trough. Journal of Fish Biology 50, 1-17.

Kiriakoulakis, K., Freiwald, A., Fisher, E., Wolff, G.A., 2007. Organic matter quality and supply to deep-water coral/mound systems of the NW European Continental Margin. International Journal of Earth Sciences (Geologische Rundschau) 96, 159-170.

Klages, M., Thiede, J., Foucher, M., 2004. The Expedition ARKTIS XIX/3 of the Research Vessel Polarstern in 2003. Reports on Polar and Marine Research 488. AlfredWegener-Institut für Polar- und Meeresforschung, Bremerhaven, 355 pp.

Koenig, C.C., Shepard, A.N., Reed, J.K., Coleman, F.C., Brooke, S.D., Brusher, J., Scanlon, K.M., 2005. Habitat and fish populations in the Oculina cora ecosystem of the Western Atlantic 41, 795-805American Fisheries Society Symposium 41, 795-805.

Koslow, J.A., 2007. The silent deep. University of Chicago Press 270 pp.
Krieger, K.J., Wing, B.L., 2002. Megafauna associations with deep-water corals (Primnoa spp.) in the Gulf of Alaska. Hydrobiologia 471, 83-90.

Le Danois, E., 1948. Les Profondeurs de la Mer. Payot, Paris 303 pp.

Le Guilloux, E., Hall-Spencer, J.M., Söffker, M., Olu, K., 2010. Association between the squat lobster Gastroptychus formosus and cold-water corals in the North Atlantic. Journal of the Marine Biological Association U. K 90, 1363-1369.

Lorance, P., Uiblein, F., Latrouite, D., 2002. Habitat, behaviour, and colour patterns of orange roughy Hoplosthethus atlanticus (Pisces: Trachichthyidae) in the Bay of Biscay. Journal of the Marine Biological Association U.K 82, 321-331.

Lorance, P., Trenkel, V.M., 2006. Variability in natural behaviour, and observed reactions to an ROV, by mid-slope species. Journal of Experimental Marine Biology and Ecology 332, 106-119.

Mauchline, J., Gordon, J.D.M., 1984. Feeding and bathymetric distribution of the gadoid and morid fish of the Rockall Trough. Journal of the Marine Biological Association U.K 64, 657-665.

Merrett, N.R., 1992. Demersal ichthyofaunal distribution in the abyssal eastern North Atlantic, with special reference to Coryphaenoides (Nematonurus) armatus (Macrouridae). Journal of the Marine Biological Association U.K 72, 5-24.

Merrett, N.R., Gordon, J.D.M., Stehmann, M., Haedrich, R.L., 1991. Deep demersal fish assemblage structure in the Porcupine Seabight (eastern North Atlantic): slope sampling by three different trawls compared. Journal of the Marine Biological Association U.K. 71, 329-358.

Metaxas, A., Davis, J., 2005. Megafauna associated with assemblages of deep-water gorgonian corals in Northeast Channel, off Nova Scotia, Canada. Journal of the Marine Biological Association U.K. 85, 1381-1390.

Miller, B.E., 2003. Population estimates and habitat types of bottom fish assessed by a remotely operated vehicle (ROV) around the San Juan Islands, Washington. Master's Thesis, Friday Harbor Laboratories, Department of Biology, Seattle, unpublished.

Morgan, L.E., Etnoyer, P., Scholz, A.J., Mertens, M., Powell, M., 2005. Conservation and management implications of deep-sea coral and fishing effort distributions in the Northeast Pacific Ocean. In: Freiwald, A., Roberts, J.M. (Eds.), Cold-water Corals and Ecosystems. Springer-Verlag, Berlin-Heidelberg, pp. 1171-1187.

Mortensen, P.B., 2001. Aquarium observations on the deep-water coral Lophelia pertusa (L., 1758) (Scleractinia) and selected associated invertebrates. Ophelia 54 (2), 83-104.

Mortensen, P.B., Buhl-Mortensen, L., Gebruk, A.V., Krylova, E.M., 2008. Occurrence of deep-water corals on the Mid-Atlantic Ridge based on MAR-ECO data. DeepSea Research II 55, 142-152.

Myers, A.A., Hall-Spencer, J., 2004. A new species of amphipod crustacean, Pleusymtes comitari sp. nov., associated with gorgonians on deep-water coral reefs off Ireland. Journal of the Marine Biological Association U.K 84, 1029-1032

Parrish, F.A., 2006. Precious corals and subphotic fish assemblages. Atoll Research Bulletin 543, 425-438.

Reed, J.K., Weaver, D.C., Pomponi, S.A., 2006. Habitat and fauna of deep-water Lophelia pertusa coral reefs off the souteastern U.S.: Blake plateau, Straits of Florida, and Gulf of Mexico. Bulletin of Marine Science 78, 343-475.

Roberts, J.M., Henry, L.-A., Long, D., Hartley, J.P., 2008. Cold-water coral reef frameworks, megafaunal communities and evidence for coral carbonate mounds on the Hatton Bank, north east Atlantic. Facies 54, 297-316.

Ross, S.W., Quattrini, A.M., 2007. The fish fauna associated with deep coral banks off the southeastern United States. Deep-Sea Research I, 975-1007.

Stoner, A.W., Ryer, C.H., Parker, S.J., Auster, P.J., Wakefield, W.W., 2008. Evaluating the role of fish behavior in surveys conducted with underwater vehicles. Canadian Journal of Fisheries and Aquatic Sciences 65, 1230-1243.

Thiem, Ø., Ravagnan, E., Fosså, J.H., Berntsen, J., 2006. Food supply mechanisms for cold-water corals along a continental shelf edge. Journal of Marine Systems 60, 207-219.

Trenkel, V.M., Francis, R.I.C.C., Lorance, P., Mahévas, S., Rochet, M.-J., Tracey, D.M., 2004b. Availiability of deep-water fish to trawling and visual observation from a remotely operated vehicle (ROV). Marine Ecology Progress Series 284 293-303.

Trenkel, V.M., Lorance, P., Mahévas, S., 2004a. Do visual transects provide true population density estimates for deepwater fish? ICES Journal of Marine Science 61, 1050-1056.

Uiblein, F., Lorance, P., Latrouite, D., 2002. Variation in locomotion behaviour in northern cutthroat eel (Synaphobranchus kaupi) on the Bay of Biscay continental slope. Deep-sea Research I 49, 1689-1703.

Uiblein, F., Lorance, P., Latrouite, D., 2003. Behaviour and habitat utilisation of seven demersal fish species on the Bay of Biscay continental slope, NE Atlantic. Marine Ecology Progress Series 257, 223-232.

Wheeler, A.J., Beck, T., Thiede, J., Klages, M., Grehan, A., Monteys, F.X., Polarstern ARK XIX/3a Shipboard party, 2005. Deepwater coral mounds on the Porcupine bank, Irish Margin: preliminary results from the Polarstern ARK XIX/3a ROV cruise.. In: Freiwald, A., Roberts, J.M. (Eds.), Cold-water Corals and Ecosystems. Springer-Verlag, Berlin-Heidelberg, pp. 393-402.

Whitehead, P.J.P., Bauchot, M.L., Hureau, J.C., Nielsen, J., Tortonese, E., 1989. Fishes of the North-eastern Atlantic and Mediterranean/Poissons de l'Atlantique du Nord-Est et de la Méditerranée. Unesco, Paris.

Widder, E.A., Robison, B.H., Reisenbichler, K.R., Haddock, S.H.D., 2005. Using red light for in situ observations of deep-sea fishes. Deep-Sea Research I 52, 2077-2085.

Witherell, D., Coon, C., 2000. Protecting Gorgonian corals off Alaska from fishing impacts In: Proceedings of the Nova Scotian Institute of Science, Nova Scotia Museum, Halifax, Canada, pp. 117-125. 